\title{
Applying adaptive management in resource use in South African National Parks: A case study approach
}

\author{
Authors: \\ Kelly Scheepers ${ }^{1}$ \\ Louise Swemmer ${ }^{2}$ \\ Wessel J. Vermeulen ${ }^{3}$ \\ Affiliations: \\ ${ }^{1}$ CSIRO Ecosystem Sciences, \\ Winnellie, Australia \\ ${ }^{2}$ Savanna and Arid Parks, \\ South African National Parks, \\ South Africa \\ ${ }^{3}$ Scientific Services (Knysna), \\ South African National Parks, \\ South Africa \\ Correspondence to: \\ Kelly Scheepers \\ Email: \\ kelly.scheepers@csiro.au \\ Postal address: \\ CSIRO Ecosystem Sciences, \\ PMB 44 Winnellie, NT 0822, \\ Australia

\section{Dates:} \\ Received: 19 Apr. 2010 \\ Accepted: 08 Mar. 2011 \\ Published: 13 May 2011 \\ How to cite this article: \\ Scheepers, K., Swemmer \\ L. \& Vermeulen, W.J. \\ 2011, 'Applying adaptive \\ management in resource \\ use in South African \\ National Parks: A case study \\ approach', Koedoe 53(2), Art. \\ \#999, 14 pages. doi:10.4102/ \\ koedoe.v53i2.999
}

\section{(C) 2011. The Authors.} Licensee: OpenJournals Publishing. This work is licensed under the Creative Commons Attribution License.
South African National Parks (SANParks) has a history of formal and informal natural resource use that is characterised by polarised views on national conservation interests and benefits to communities. Current efforts aim to determine the sustainability of existing resource use in parks and to formalise these activities through the development of resource use protocols. The resource use policy of SANParks outlines principles for sustainable resource use, including greater involvement of local communities in management of protected areas and an adaptive management approach to determining sustainable use levels. This paper examines three case studies on plant use in national parks with regard to the development of criteria and indicators for monitoring resource use, and the role of thresholds of potential concern in measuring effectiveness of managing for sustainable use levels. Opportunities and challenges for resource use management are identified. Findings show that platforms for discussion and knowledge sharing, including research committees and community associations, are critical to building relationships, trust and a shared vision of sustainable resource use between stakeholders. However, additional capacity building is needed to enable local community structures to manage internal social conflicts and jealousy, and to participate fully in monitoring efforts. Long-term monitoring is essential for developing flexible harvest prescriptions for plant use, but this is a time-consuming and resource-intensive exercise. Flexible management strategies are difficult to implement and sometimes command-and-control measures are necessary to protect rare or endangered species. A holistic approach that considers resource use in national parks as a complement to broader community development initiatives offers a way forward.

Conservation implications: There is no blueprint for the development of sustainable resource use systems and resource use is often addressed according to multiple approaches in national parks. However, the SANParks resource use policy provides a necessary set of guiding principles for resource use management across the national park system that allows for monitoring progress.

\section{Introduction}

Most protected areas are established with the primary goal to conserve biodiversity; however, the other roles protected areas play in people's livelihoods are increasingly recognised. These include the provision of ecosystem services and support of socio-economic development opportunities (Scherl et al. 2004). In South Africa, as elsewhere in the world, the establishment of many protected areas have been associated with colonial processes of displacement and dispossession, and protected area management has been subject to exclusionary policies (Abbot \& Mace 1999; Nagothu 2001). Consequently, strong arguments are also made for the provision of benefits from conservation to historically disadvantaged groups (Scherl et al. 2004; Von Maltitz \& Shackleton 2004; Willis 2004).

In response to the 'fortress conservation' model adopted widely across Africa to protect remnants of pristine habitats and recover declining wildlife populations, more socially responsible models have emerged as alternatives in recent years (Hoole \& Berkes 2010; Scherl et al. 2004). These models are more inclusive of the values and aspirations of local peoples and encourage greater involvement by local communities in protected area management (Scherl et al. 2004). Various community-based conservation initiatives, such as wildlife management areas in Zimbabwe and community conservancies in Namibia, have aimed to diversify the conservation economy to include nature-based tourism and the commercialisation of natural resource use (Hoole \& Berkes 2010; Lindsey, Roulet \& Romañach 2007). Zimbabwe's Communal Areas Management Programme for Indigenous Resources (CAMPFIRE) is perhaps the most famous African example of how local communities can benefit from being granted commercial rights to use wildlife. However, more recently, major socio-economic factors related to the fast track of land reform in Zimbabwe, such as high unemployment, rampant inflation, food insecurity and social unrest, have threatened the long-term sustainability of the wildlife industry (Clover \& Eriksen 2009). 
In South Africa, contractual national parks offer a potential win-win solution for conservation and communities through joint management of the land and its resources (Reid \& Turner 2004). Contractual parks provide a way to expand the national network of protected areas with the inclusion of land that cannot be bought and/or on which mining rights will not be released. The concept was first developed when the government could not expropriate powerful commercial land owners from land wanted for conservation but has more recently been applied in the context of land claims on national parks by communal land owners (Reid et al. 2004). For communities, contractual parks represent a way to enforce their land ownership rights and gain access to conservation, tourism and natural resource use benefits through comanagement arrangements with South African National Parks (SANParks). However, most contractual parks are of little biodiversity conservation significance, as compared to the greater national park area of which they form part (Reid et al. 2004). Contractual parks, as a model for social redress, have also been criticised for reasserting state or elite control over resources, perpetuating the dominance of western management frameworks, contributing inadequately to capacity building, and exacerbating the skewed distribution of benefits in South Africa (Murphree 2000; Reid \& Turner 2004). Yet, as with most recent initiatives, these issues perhaps represent the to-be-expected 'teething problems' of a more participatory approach to management compared to the strict 'fines and fences' policies of the past (Reid et al. 2004).

In addition, the SANParks resource use policy (2008) allows a wide range of stakeholders to use park resources for everyday purposes. There are many current examples of both informal and formal resource use in national parks. Certain of these practices are being allowed, and in some cases supported by SANParks, with the long-term view towards developing monitoring systems and establishing local governance arrangements for sustainable resource use that incorporate local and scientific knowledge. A number of flagship projects, which span varied stakeholder groups' use of multiple resources across the national park network, serve as case studies of the implementation of the resource use policy. Three such case studies are presented in this paper.

This study examines the role of sustainable resource use as a strategy for providing 'benefits beyond boundaries' in South African national parks. A brief description of the current context and driving factors of resource use in national parks is provided. Using the national resource use policy as a framework for comparing case studies on plant resource use across three national parks, we then examine the effectiveness of the SANParks management strategy for ensuring sustainable use and providing resource users with socio-economic benefits.

\section{Setting the policy scene for South Africa}

SANParks has a long history of natural resource use. However, whereas incidents of illegal poaching and resource use were largely isolated, opportunistic and for customary use purposes in the past, high demands for improved access to park resources, driven by an increasingly complex set of socio-political factors under the new political dispensation in South Africa (after 1994), have recently shaped policy development and implementation. Resource use can no longer be managed on a case-by-case basis because of the growing diversity of resource users, natural resources and resource use strategies that support human livelihoods.

Resource harvesting currently takes place in national parks as part of core business, nature-based tourism activities, research, and in the spirit of 'benefits beyond boundaries'. The resource users comprise several stakeholder groups, including the public, staff, conservation partners, researchers, local entrepreneurs and small business owners, tourists and neighbouring communities. In particular, there has been strong emphasis on the development of small- to mediumscale enterprises for sustainable resource use, such as community nurseries and arts-and-crafts centres. This marks a shift in resource use strategies, moving from customary use towards greater reliance on the market economy.

Past experiences have shown that once resource use entitlements have been granted they are difficult to amend. SANParks has therefore also had to implement a management system that promotes learning by doing (Cundill \& Fabricius 2009; Stankey, Clark \& Bormann 2005). Strategic adaptive management entails a participatory process to define management challenges, strategise future directions, implement management actions and evaluate their effectiveness in meeting management objectives.

However, because national-scale drivers such as social redress and poverty alleviation influence resource use in national parks, localised management solutions alone cannot bridge the divide between conservation policy and management for ecosystem integrity. Resource use management requires a systems approach that recognises linkages between national parks and their surrounds and acknowledges a complex definition of sustainability with ecological and socio-economic components (Fabricius 2004; Hansen \& DeFries 2007).

Despite the best efforts of national parks to conserve biodiversity and ecosystem integrity, threats such as unsustainable resource use persist because ecological functions and processes often occur over larger spatial scales (Hansen \& DeFries 2007). To ensure that ecosystems retain the ability to renew themselves, additional land is needed for the expansion of national parks given limited sites suitable for conservation, competing land development options and growing tensions over the national conservation budget. Consequently, creative ways to supplement formal conservation efforts are required. This involves the implementation of policy reforms and market-based incentives to encourage private and communal land owners to invest in conservation as a competitive land use option (Bulte, Van Kooten \& Swanson 2003). Bioregional plans, contractual national parks and stewardship arrangements are examples of such initiatives. However, as secure land 
ownership rights are central to these community-based conservation models, benefit sharing is tied to a narrow definition of the legitimate resource users as land title holders. Ultimately, there is a need for a wider-reaching policy that addresses people's everyday resource use needs and which can complement land management solutions.

\section{The SANParks resource use policy as a framework for case study comparison}

The SANParks resource use policy (SANParks 2008) deals exclusively with resource use rights rather than land rights. This is significantly different from the application of contractual park agreements. The policy first aims to regulate existing resource use in national parks but also allows for the identification of new opportunities to provide socioeconomic benefits to people. Legitimate resource users are defined as all stakeholders who influence or are influenced by management decisions pertaining to resource use in national parks.

A complex systems view of sustainable resource use acknowledges that the direct, consumptive use of park resourcesalone cannot meet people's demands. Consequently, SANParks supports investments in collaborative partnerships and networks that link local resource users to wider socio-economic development initiatives. In particular, the current policy highlights opportunities for sustainable resource use associated with the eradication of invasive alien species in national parks through the expanded public works programme.

Sustainability also takes on a complex meaning, as the policy calls for an adaptive management approach that links monitoring to management, combines scientific and local knowledge, and allows for flexible rules governing resource use. Adaptive management requires change indicators to monitor trends in resource use, where ecological sustainability is defined by a rate of use that is less than that of the natural rate of replenishment of the resource. However, rather than using fixed targets, SANParks measures sustainable resource use against thresholds of potential concern (TPCs). This approach allows for a certain amount of ecosystem change brought about by resource use, provided it remains within the natural limits of variation. Consequently, TPCs create a feedback loop between monitoring and management, which serves as an early detection system for undesirable changes to ecosystems and prompts informed management interventions to promote cyclical learning (Biggs \& Rogers 2003; Parr, Woinarski \& Pienaar 2009).

There is also a socio-economic component to sustainable resource use, as the process of developing monitoring indicators and TPCs is resource intensive and time consuming. This process entails the active involvement and support of all stakeholders to ensure effective monitoring of sustainable resource use and adherence to the rules. The SANParks policy does not explicitly call for the co-management of resources; however, greater stakeholder participation in resource use management is encouraged, including the incorporation of local knowledge in monitoring and evaluation systems. The roles and responsibilities of stakeholders vary according to the local context and purpose of the resource use. For example, community projects that address historical disadvantage through local economic development and capacity building are distinguished from commercial big business and afforded special recognition and greater 'hands-on' support by SANParks. On the contrary, commercial developers, while expected to adhere to sustainable resource use practices, are also required to contribute financially and otherwise to the development and implementation of monitoring systems.

Flexible rules that are informed by the zonation of harvest and control areas, multiple indicators of change, TPCs for different harvest intensities and provisional harvesting permits also support sustainable resource use. The zonation of use and no-use areas within national parks allow for greater flexibility when setting TPCs. Multiple overlapping sets of rules make it more difficult for opportunits and outsiders to abuse the system. Provisional harvesting permits enable issues that arise from the management process to be dealt with in a timely manner and facilitate feedbacks between monitoring and management.

The following case studies discuss the implementation of these principles for sustainable resource use. In particular, they focus on the use of an adaptive management approach to monitoring sustainable resource use, which incorporates scientific and local knowledge and informs flexible rules of management.

\section{Case study 1: Seven-weeks fern (Rumohra adiantiformis) harvesting in the Garden Route National Park}

\section{Introduction}

The fronds (leaves) of the seven-weeks fern (Rumohra adiantiformis [G. Forst.] Ching) are extensively used in flower arrangements, both locally and abroad. Harvesting of $R$. adiantiformis fronds from natural forests in the southern Cape started as far back as 1970 when private land owners were issued permits to harvest small quantities on their lands for the local flower market (Milton \& Moll 1988). However, owing to rising demands and the high economic value of the resource, which outweigh the risk of prosecution and fines, illegal harvesting escalated (Geldenhuys \& Van der Merwe 1988).

In 1982, approximately 4000 ha of indigenous state forest land was released for the commercial harvesting of R. adiantiformis fronds as a means to address the high demand and to counteract illegal harvesting. However, too little was known about the species' ecology, dynamics and productivity to inform sustainable harvest practices. Following an adaptive management approach, harvest prescriptions for the species 
were developed and refined as research results became available.

\section{Socio-economics aspects}

The species is solely harvested for commercial purposes and the sale of $R$. adiantiformis fronds from state forest land is managed through an open tender process. Given the commercial value of the product and growing demand for access, entrepreneurs with a business drive, financial capacity and a vested interest in the resource became the key stakeholders. State-funded research was initiated to advise managers of sustainable harvesting practices while fern harvesting contractors commissioned additional research and studies on the ecology and dynamics of the species (Geldenhuys \& Van der Merwe 1986; Milton \& Moll 1987). The industry dictates minimum requirements for the commercial sale of the resources and only fully matured, hardened fronds without necroses or other blemishes are considered usable for the florist trade. Frond size, form and colour also constitute important criteria for product quality (Geldenhuys \& Van der Merwe 1988). However, as these criteria were not always clearly defined, fern populations were initially harvested every five weeks with no restrictions on the number of fronds that could be harvested.

As stricter harvest prescriptions were implemented, the harvesting of fronds from state forests was insufficient to meet industry demands for a maximum sustainable yield. The industry had to find alternatives to meet the demand, which resulted in the establishment of commercial nurseries in addition to fern stands that had been established under commercial pine plantations. The alternatives to harvesting wild populations of the resource ensured not only the economic sustainability of the industry but also the extension of socio-economic benefits through the creation of additional jobs (Kok 1998). With harvesting from the wild becoming less attractive to large commercial players, a community fern harvesting project was initiated to supply commercial operators (Vermeulen, Du Plessis \& Herd 2005). In this way, poor and unemployed individuals (especially women) living close to the forest (the target group) had become direct beneficiaries from fern harvesting.

At its peak, the income from fern sales exceeded that of indigenous timber (Vermeulen 2009), but, more importantly, a new industry had been developed with associated large socio-economic benefits. Forest management had to adapt to the harvesting of a non-timber forest product during a time when commercial timber harvesting was the primary focus of resource management. Similarly, the industry had to shift from the harvesting of wild populations to alternative resources to meet demand and maintain benefits.

\section{Ecological studies}

The generic process of determining sustained yield for forest products and developing harvest prescriptions has been well documented (Cunningham 2001; Geldenhuys 2000; Peters
1996). This process has also guided research and monitoring to inform harvest prescriptions for R. adiantiformis (Figure 1). Two key components of the process are:

- delineating the potential resource area following studies on the habitat and distribution of the target species, and

- studying the population dynamics, demography and reproductive phenology of the species.

The section that follows is a summary and review of research results as they became available and shows how these impacted on the formulation of management prescriptions through a process of adaptive management.

\section{Community association and delineation of the harvest area}

To identify and accurately map the potential harvest area for a species, knowledge of its habitat and distribution and insight into its community association are required (Figure 1). Based on earlier forest type classification (Von Breitenbach 1968) and with consideration to local knowledge, forest areas with potential for commercial fern harvesting were identified and mapped. The species was found to have a patchy distribution and to occur in fairly dense clusters in wet and moist high forest, which made the accurate mapping of the potential harvest area difficult.

A detailed phytosociological study of the forest vegetation in the southern Cape, including a description of both tree and ground flora communities was concluded in 1993 (Geldenhuys 1993). R. adiantiformis was found to be an important component of several ground flora communities and to occur in scarp, platform and mountain forests. Of major significance was that $R$. adiantiformis is frequently associated with specific understorey communities in tall to high, moist regrowth forest, on a variety of sites in mountain, foothill, platform and coastal scrub vegetation. It represents an early regrowth phase (after disturbance by, for example, fire) and should eventually be suppressed by shrub understorey and tree regeneration (Geldenhuys \& Van der Merwe 1994).

\section{Population structure}

Knowledge of the population structure and demography of the target species is essential in the development of a system for sustainable use and in assessing potential yield (Figure 1). This was also a focus point of research. The results showed that the population structure and dynamics of the species vary temporally and spatially (within and between populations) and are affected by the density of the tree and shrub layers (Geldenhuys \& Van der Merwe 1988; Milton \& Moll 1987).

Plant density ranges between zero and 14 plants per square metre, with an average of four plants per square metre. The number of fronds per plant, which proved to be an important variable in the formulation of harvest prescriptions for the species, varies between two and three, depending on site and season (Geldenhuys \& Van der Merwe 1988, 1994; Milton \& Moll 1987). This resulted in a harvest prescription that 


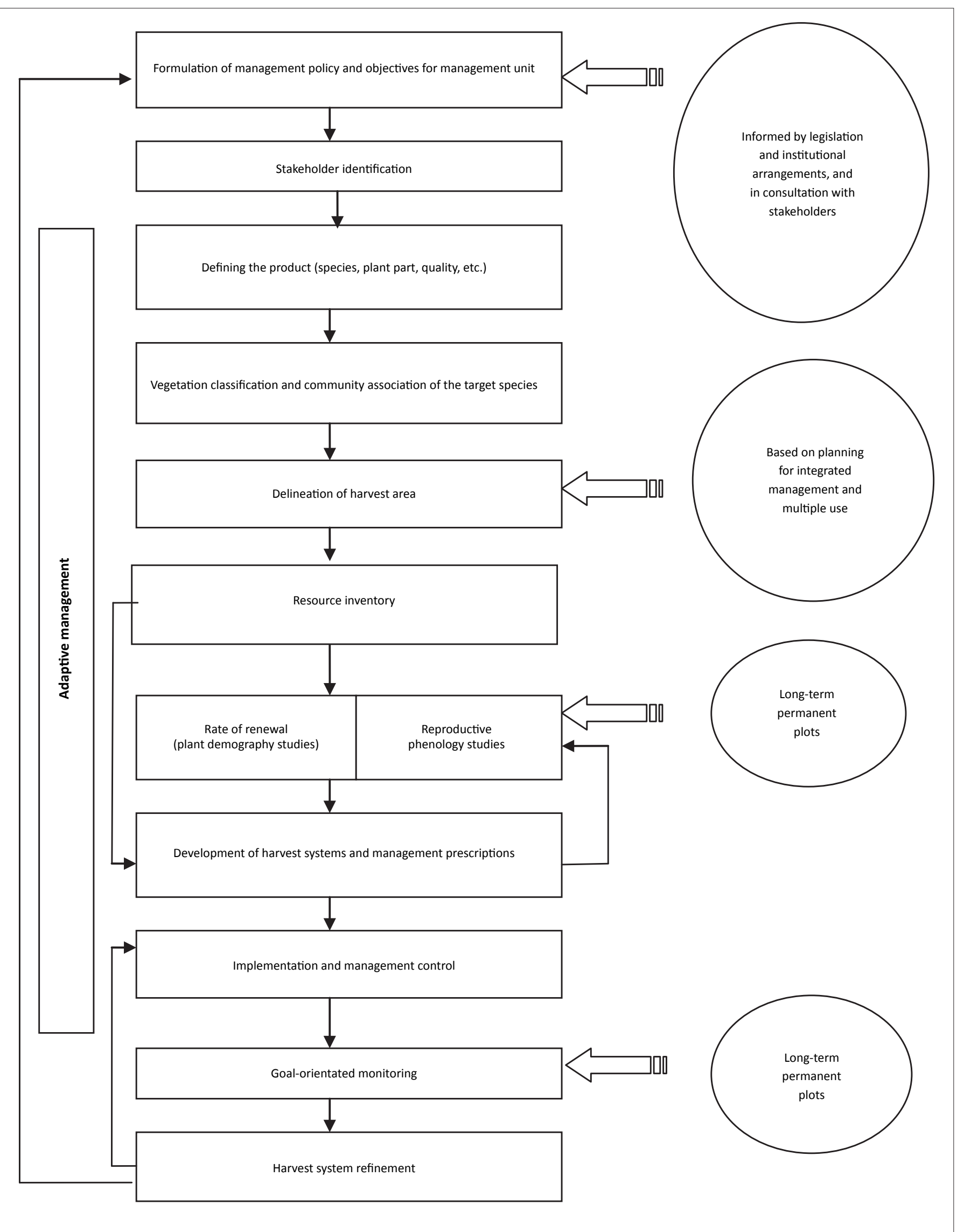

FIGURE 1: Flow diagram indicating the generic process for the development of harvest systems and management prescriptions for resource use (adapted from Vermeulen, W.J., 2009, 'The sustainable harvesting of non-timber forest products from natural forests in the southern Cape, South Africa: Development of harvest systems and management prescriptions', PhD thesis, Department of Conservation Ecology and Entomology, Stellenbosch University). 
restricted harvesting to only $50 \%$ of the harvestable fronds per plant.

Frond size is another critical component for setting harvest prescriptions and is affected by factors such as habitat, stand density, season of bud production and rainfall (Geldenhuys \& Van der Merwe 1988, 1994; Milton \& Moll 1987). An average frond length of $48 \mathrm{~cm}$ was recorded for floodplain populations, compared to $27 \mathrm{~cm}$ for ridgetop populations. Together with market demands, this informed the decision to set the minimum frond length for harvesting at $25 \mathrm{~cm}$.

\section{Plant demography and reproductive phenology}

Apart from population structure, information on frond development, rate of production and frond longevity was essential in refining harvest prescriptions, especially with regard to the harvest cycle. Study of the reproductive phenology of $R$. adiantiformis allowed the optimum harvest season to be identified.

The rate of frond production by $R$. adiantiformis was low compared to the rate of exploitation. Long-term monitoring indicated an annual production of between one and three fronds per plant (Milton \& Moll 1987) or two fronds per square metre, depending on stand density (Geldenhuys \& Van der Merwe 1994). It was also found that bud initiation began during July and August and peaked between September and November (Geldenhuys \& Van der Merwe 1988, 1994). Considering the above, the period from January to March (i.e. before the onset of bud formation) could be regarded as the least sensitive to harvesting, and the opposite for the period between September and November. Monitoring also showed that mature fronds increase in proportion to dominate from January to March, with a peak between December and January, and the lowest number in July (Geldenhuys \& Van der Merwe 1994). This finding was critical for assessing the potential yield and scheduling harvest operations.

Phenological events are not always predictable because they are synchronised with rainfall and temperature fluctuations. However, because a reliable supply of the resource is required for a viable socio-economic industry, a moratorium on harvesting during certain times of the year would not have been a suitable management option. The problem was partly addressed through a longer harvest cycle of 15 months, which would ensure that a particular area was not harvested consistently during the same time of year.

\section{Impact of harvesting}

Assessing the impact of harvesting on individual plants and the resource as a whole (Cunningham 2001) is an essential part of refining harvest prescriptions through an adaptive management approach. With an industry dependent on the $R$. adiantiformis resource, research into the impact of frond harvesting was a priority. Experimental harvesting at different intensities and frequencies was subsequently initiated (Geldenhuys \& Van der Merwe 1986, 1988; Milton 1987a, 1987b, 1991; Milton \& Moll 1987).
Monitoring results indicated a significant decline in mature frond size for partial and total defoliation treatments at a harvest rotation of less than 12 months. Overharvesting also led to plant mortality and a reduction in harvestable fronds and impacted negatively on rhizome growth, the timing of budding and spore production. In addition, plant recovery after overharvesting was slow. Milton (1987a) found no significant increase in the average length of fronds on defoliated plants (two cycles, nine-month interval) during a 22-month rest period.

\section{Adaptive management and refinement of harvest prescriptions}

Preliminary research results to inform harvest prescriptions for the species were presented at Rumohra research committee meetings attended by researchers, managers and representatives from the industry in 1984 and 1985, followed by formal reports and publications (viz. Geldenhuys \& Van der Merwe 1986, 1988, 1994; Milton 1987a, 1987b, 1991; Milton \& Moll 1987, 1988). The interpretation of the findings and refinement of harvest prescriptions were complicated by spatiotemporal variation in the research, drought during parts of the research period (Geldenhuys \& Van der Merwe 1994) and the disturbance of some research sites due to uncontrolled fern picking, which demonstrated the importance of setting aside unharvested areas for control purposes.

The sensitivity of the species to overutilisation, as reflected especially by the decline in frond size and the slow recovery rate, could be regarded as the most important trigger for the revision of the harvest prescriptions (Vermeulen 2009). The long-term implications for the industry, if harvest rates were not aligned with the natural rate of production for the species, were therefore realised. Through the adaptive management approach, and based on results of population dynamics and plant demography research and monitoring, the initial harvest cycle of 5 weeks was increased to 8 weeks, then to 16,26 and 52 weeks, and is currently set at 15 months. Total defoliation was prohibited and harvest intensity restricted to $50 \%$ of mature fronds per plant, with a minimum frond length of $25 \mathrm{~cm}$.

Phytosociological studies indicated that $R$. adiantiformis is often associated with regrowth forest. The potential harvest area can therefore not be fixed for the long term but should be considered at a landscape level, taking into account the natural ecological processes and disturbance regimens. This further emphasises the relevance of an adaptive management approach to $R$. adiantiformis harvesting. The formulation of a clear definition for a usable frond, based on market demands as well as ecological considerations, proved to be an important management tool in controlling harvest operations, enforcing harvest prescriptions and minimising wastage.

The need for continued monitoring to assess the impact of harvesting and to gather further information on fern stand development was stressed by Geldenhuys (1994). To this 
end, and to refine harvest prescriptions further, various longterm monitoring projects were initiated in and outside fern picking areas (Geldenhuys \& Van der Merwe 1994; Kok 1998). The results indicated that the current harvest prescriptions provide for the sustainable harvesting of the species. However, to ensure optimum use given spatiotemporal variation in the distribution of harvestable fern stands harvest areas should be redefined where required (Vermeulen 2009). Specific indicators of change are frond size, number of usable fronds and yield from picking areas. Specific TPCs were not historically developed for the species but a consistent decline in fern frond size in picking areas triggered the extension of the harvest rotation. The gradual decline in harvest potential of the resource in picking areas, detected through continued monitoring (Vermeulen 2009), was also of concern. The same trend, however, was recorded in control areas outside of picking areas, supporting the argument for a natural decline in fern densities in regrowth forest. TPCs for the harvesting of the species need to take such spatiotemporal variation into consideration. However, other drivers of change (e.g. climate) also need to be considered in future research.

\section{Lessons learnt from case study}

Key lessons were learnt from the development of a harvest system for R. adiantiformis.

- The precautionary principle (Cooney 2004) should be followed with the development of interim harvest prescriptions. Given the negative impact of harvesting on fern populations in accordance with initial prescriptions, it was apparent that the precautionary principle was not applied effectively. This was exacerbated by the slow recovery rate following overharvesting.

- Knowledge gaps should be identified and research objectives clearly set. With the complexities of plant populations and the dynamic nature of forest ecosystems, it is difficult to predict long-term yield or the impact of resource use. The development and refinement of harvest prescriptions should be ongoing, which require continued monitoring at different levels.

- The identification of indicators of change and the development of TPCs could support sustainable resource use. Instead of fixed measures, TPCs should be developed and refined as the knowledge base on the resource and ecosystem functioning is broadened through research and long-term monitoring.

- The costs of developing, implementing and monitoring sustainableharvest systems should notbeunderestimated. Management agencies should ensure that the necessary resources are available when initiating resource use programmes.

- Where resources are harvested for commercial use, the developer should be prepared to contribute towards scientific studies on the target species to inform management prescriptions. In the case of $R$. adiantiformis, research was conducted in a complementary way, funded and initiated by the state and the commercial developers.

- Close cooperation and knowledge sharing between the different role players are essential. The $R$. adiantiformis research committee was indispensable as a platform for feedback and discussions between researchers, managers and industry. The needs of the different role players also had to be understood. Resource managers had to appreciate the economic potential of the resource and the loss of potential business opportunities if access to the resource was restricted. Similarly, businesses had to appreciate the importance of ecological and economic sustainability and the complexities and time span associated with the development of scientifically based harvest prescriptions.

- Applying the zonation principle whereby use and nouse areas are defined is essential for integrated resource management. Not only does it allow for assessing the sustainability of the resource being harvested but also for the spatial separation of incompatible management practices to accommodate multiple forest management objectives.

- The case study demonstrated the importance of the development of alternative resources where desirable, not only to meet demand and reduce pressure on resources from the wild, but also to optimise socioeconomic benefits through the commercialisation of highvalue products.

\section{Case study 2: Pepper-bark tree (Warburgia salutaris) harvesting in the Kruger National Park Introduction}

It is estimated that approximately 27 million South Africans rely on traditional medicine (Mander 1998). Considering that $34 \%$ of the population are between the ages of 15 and 65 years and have no fixed employment (Botha, Witkowski \& Shackleton 2004), the medicinal plant trade makes an important contribution towards human livelihoods. Tissue from the Pepper-bark tree (Warburgia salutaris [Bertol.f.] Chiov.) is a popular traditional medicine that is used and traded throughout Southern Africa (Botha, Witkowski \& Shackleton 2004). The bark, stems, roots and leaves are used to treat numerous health complaints, including colds, respiratory complaints, fever, malaria, influenza, coughs, venereal diseases, abdominal pain, constipation, cancer, rheumatism, stomach ulcers and headaches (Diederichs 2006). As such, the demand for W. salutaris products is high and most tree populations have been intensely impacted. The historical distribution of W. salutaris stretches from Kenya and Tanzania in east Africa, down through Mozambique and Zimbabwe, to South Africa and Swaziland in the south. It is also found in Madagascar. In South Africa, the species was recorded widely in KwaZulu-Natal, Mpumalanga and the Limpopo province, but is thought to have been extirpated from much of this area as a result of high harvesting intensities and habitat destruction. W. salutaris is listed as both nationally and internationally endangered, according to the SANBI Red List (SANBI 2009) and the IUCN Red List (IUCN 2010), respectively.

The Kruger National Park (KNP) is host to what is believed to be the largest remaining wild populations of $W$. salutaris 
in the Limpopo province. Although the plants are located within the boundaries of the park, illegal harvesting of bark from $W$. salutaris trees occurs. This threatens the park's mandate of biodiversity protection. On the contrary, denying communities access to this valuable resource contributes towards negative park-neighbour relations, which, in turn, threaten to undermine other park management objectives that pertain to access and benefit sharing. Other potential threats to the plants include the possible negative effects of climate change, limited reproductive behaviour and genetic isolation of subpopulations. In response, SANParks has embarked on a multidisciplinary programme that aims to promote and facilitate the conservation of W. salutaris in the KNP and the surrounding areas, in order to benefit both current and future generations (Swemmer 2010).

\section{Socio-economic aspects}

Traditional health practitioners (THPs), who operate locally as well as in urban areas, are the primary users of $W$. salutaris tissue. In the past, medicinal plant harvesting was subsistence based, and regulated by local customary laws and harvesting methods that promoted ecological sustainability. However, more recently these traditional practices have been threatened by outsiders using commercial approaches which adopt highintensity, high-impact harvesting strategies which are less ecologically viable and sustainable in the long term (Natural Justice 2010). In the Limpopo province, $W$. salutaris is in high demand by local THPs and commercial herbalists or 'muti hunters' (Natural Justice 2010). Most THPs interviewed in the province indicated that they had never seen a $W$. salutaris tree despite their use of its bark (anon., pers. comm.). This is mainly because the tree is so rare that THPs are forced to purchase its bark either as whole pieces or as powder on the local markets, often at a high price (anon., pers. comm.). As a result of this scarcity, the market value of $W$. salutaris tissue has increased remarkably over the past decade. Many of the local THPs have not heard of using the leaves as opposed to the bark, although studies have shown that the chemical and healing properties of these two tree parts are similar. $W$. salutaris leaves are not readily available in the local markets (anon., pers. comm.).

\section{Ecological studies}

As a result of the threatened status of $W$. salutaris, and an increase in illegal harvesting of the population within the $\mathrm{KNP}$, an active research, management and monitoring strategy was needed to promote the long-term survival of the species. A number of plant surveys were conducted over the past decade. The first survey was completed in 2000 and found that human impact had affected approximately $12 \%$ of the total number of stems recorded (Botha, Witkowski \& Shackleton 2004). Very few specimens of the smaller size classes $(<1.5 \mathrm{~m})$ were found (less than $10 \%$ of the population). In 2006, a second survey found that the situation had worsened, with $57 \%$ of the trees showing signs of human damage (Figure 2). The survey again reported very few individuals $(3 \%)$ in the smaller size classes, with most plants

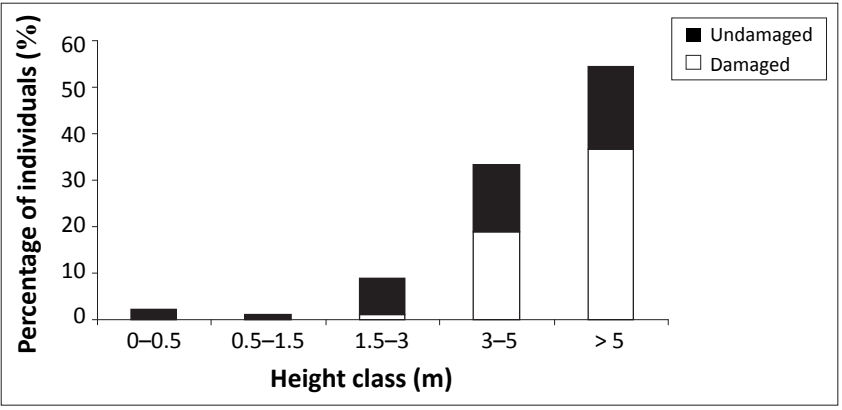

FIGURE 2: Percentage of damaged and undamaged individuals for each height class of Warburgia salutaris recorded in the Kruger National Park in 2006.

(90\%) recorded as between $3 \mathrm{~m}$ and $7 \mathrm{~m}$ tall. Almost twothirds (59\%) of the plants were multi-stemmed.

\section{Adaptive management Ecological TPCs}

These results inspired the development of the first suite of TPCs for W. salutaris (Zambatis 2006). The aim of this set of TPCs was to provide managers and researchers with indicators and acceptable limits they could then use to monitor and detect changes in the population, especially in the event that these changes were human induced. TPCs 1 and 2 related to population dynamics, and TPCs 3 and 4 to harvest impact.

TPC 1: No or very few $(<30 \%)$ adults recorded. (An adult is defined as a specimen with a primary stem diameter of at least $10 \mathrm{~cm}$. Stem diameter is measured at a point just above the basal swelling.)

TPC 2: No or very few $(<10 \%)$ juvenile plants recorded in the population. (A juvenile is defined as a specimen that is less than $1.5 \mathrm{~m}$ tall.)

TPC 3: The primary stems of at least $20 \%$ of all specimens have been ring barked and the entire plant is dead.

TPC 4: One or more primary stems of more than $60 \%$ of specimens have been debarked and/or broken but are not dead, even though the individual may be re-sprouting from the main stem below the injury point or coppicing from ground level.

The results of the 2006 survey showed that TPC 2 had been exceeded by about $7 \%$ (Table 1). It was also noted that TPC 4 was close to being exceeded. Towards the end of 2008, a number of illegal harvesting incidents took place including extensive ring barking of more than 13 stems on a single day (A. Lumbe, pers. comm.). This highlighted the need for immediate management action. Funding was obtained to implement an integrated conservation effort, which included employing a team of field rangers to patrol the area daily.

In 2009, a third survey was conducted and the results showed a further $6 \%$ increase in the proportion of damaged plants. This exceeded the limits set by TPC 4 . Again, only a small 
percentage (about $5 \%$ ) of individuals was taller than $1.5 \mathrm{~m}$ (Table 1). In addition, there was a drop of approximately $13 \%$ in the proportion of adults recorded.

\section{Discussion of existing ecological TPCs}

No or very few adults recorded (TPC 1): This TPC was designed to detect a change in the proportion of adult trees in the population. If the observed change was a reduction in proportions, as was seen between 2006 (56\%) and 2009 $(43 \%)$, it would suggest that the number of large W. salutaris plants is declining and that there may be cause for concern. However, since the TPC is based on proportions as opposed to total counts, it is not possible to ascertain whether there has been a drop in the total number of large plants or whether there has been a drop in the total proportion of large plants. The latter could be true if a large recruitment event took place, resulting in a large number of small plants, which, in turn, would reduce the proportion of large plants in the population as a whole, but not necessarily the numbers. Since the population size is small, it may be more useful to use total population counts or density counts in permanent plots to pick up more subtle changes. These options are feasible temporary alternatives when the entire population of plants is reasonably small and contained as is seen in the W. salutaris population. It is important to keep the point at which the stem diameter is measured consistent to ensure repeatability. Stems rather than individuals should be measured.

No or very few juvenile plants (TPC 2): This TPC was designed to detect changes in recruitment patterns of $W$. salutaris. It is assumed that in healthy populations, the 'reverse J' population curve would be observed with large numbers of plants in the smaller size classes, decreasing for the bigger size classes. Low proportions of juvenile plants would suggest little recruitment, which would be indicative of an unhealthy population. However, this application is not suitable for some savanna tree species that recruit sporadically during infrequent and opportunistic recruitment events. In this case, a bell-shaped distribution of size classes does not necessarily indicate a problem with the species. Unfortunately, the natural population dynamics of $W$. salutaris are not well documented. For the $W$. salutaris population in the KNP, low proportions of small plants have been recorded, namely 3\% in 2006 and 5\% in 2009. In KwaZulu-Natal, it was found that there was a very small seed set of $W$. salutaris. No seedlings were recorded and all plants had reproduced vegetatively (Hilton-Taylor et al. 1998). Similar observations were made in the KNP population. Very few seeds were found and most plants were either coppicing or joined by coppice shoots to one another. This suggests that the plants are reproducing asexually from root suckers. A measure of small individuals is useful as an indication of recruitment but, as in TPC 1, it would be more useful to use total counts or plot densities as opposed to proportions of individuals at this stage. Furthermore, using stem diameter as a measure of size classes rather than height is suggested for the modified version of this TPC.
TABLE 1: The suite of thresholds of potential concern tested using data from surveys conducted in 2006 and 2009.

\begin{tabular}{|c|c|c|c|}
\hline TPC number & Description & 2006 survey & 2009 survey \\
\hline 1 & No or very few $(<30 \%)$ adults recorded & $56 \%$ & $43 \%^{a}$ \\
\hline 2 & $\begin{array}{l}\text { No or very few juvenile plants recorded } \\
\text { ( }<10 \% \text { of all individuals) }\end{array}$ & $3 \%^{b}$ & $5 \%^{b}$ \\
\hline 3 & $\begin{array}{l}\text { The primary stems of at least } 20 \% \text { of all } \\
\text { individuals have been ring barked and } \\
\text { the entire plant is dead }\end{array}$ & $14 \%$ & $0.50 \%$ \\
\hline 4 & $\begin{array}{l}\text { One or more primary stems of more } \\
\text { than } 60 \% \text { of individuals have been } \\
\text { debarked and/or broken but are not } \\
\text { dead, even though the individual may } \\
\text { be re-sprouting from the main stem } \\
\text { below the injury point or coppicing } \\
\text { from ground level }\end{array}$ & $55 \%^{a}$ & $61 \%^{b}$ \\
\hline
\end{tabular}

The primary stems of individuals have been ring barked and the entire plant is dead (TPC 3): Although ring barking causes death of the crown above the site of damage of the effected stem, it may not be the case with a multi-stemmed plant with one or more undamaged stems. In the W. salutaris population in the KNP, most plants (59\%) are multi-stemmed (Zambatis 2006) and coppice regularly. Botha, Witkowski and Shackleton (2004) report an increased coppicing rate in individual plants that have been subjected to uncontrolled harvesting. This TPC could be modified to monitor numbers as opposed to proportions of dead stems. Monitoring proportions will be better in the long term, but since the population is small, it may be possible and preferable to do total counts.

One or more primary stems of most individuals have been debarked and/or broken but are not dead (TPC 4): This TPC was designed to use as an indicator of the proportion of damaged plants. The increasing proportion of damaged plants between 2000, 2006 and 2009 (12\%, 55\% and 61\%, respectively) is a real management concern. However, once again, a measure of numbers or plot densities as opposed to proportion of damaged stems may be a more accurate measure of impact. A measure using percentage of stems as opposed to percentage of plants may also yield more accurate results. The acceptable limit of $60 \%$ may also be too high and may have to be reduced.

\section{Managing the demand}

It is acknowledged that to conserve the $W$. salutaris population in the long term, an integrated approach involving biophysical and social research, outreach and awareness, and conservation and protection will be necessary. In 2004, the People and Conservation Department of the KNP implemented an awareness education programme focused on rare and invasive species, funded by the Development Bank of South Africa. A survey was conducted amongst local communities adjacent to the south-western boundary of the KNP with the aim of encouraging youth development in conservation challenges. The results regarding people's perceptions of the status of $W$. salutaris showed that $13 \%$ of the respondents did not know the tree and $67 \%$ of respondents have never seen one before. A further $34 \%$ of respondents 
did not know the tree was rare, but $24 \%$ said that it was not easy to find. Only $16 \%$ of the respondents said it was rare because it was used for medicine. Additional perceptions given by respondents for it's rarity included the belief that $W$. salutaris is used to make paper, is being chopped down and that it needs more water than other trees (Swemmer 2006).

Another issue addressed through the programme is the development of alternative sources to wild populations (Swemmer 2010). This is being done through a number of workshops aimed at training local THPs in the propagation of $W$. salutaris. These workshops are also used to market the use of $W$. salutaris leaves rather than bark in traditional medicine practices. The programme aims to promote access to $W$. salutaris trees in home gardens for medicinal use, as well as to enable the selling of surpluses to local and urban markets. Well-established associations of traditional healers (e.g. the Vukuzenzele Nursery and Medicinal Garden in Bushbuckridge and the Makuya Traditional Healer Association) could consider a more commercial approach to W. salutaris propagation.

So far, workshop participants have been supportive of using $W$. salutaris leaves. They have also propagated more than 600 W. salutaris cuttings successfully. Although the cuttings are being cared for by the propagation and training nursery, once established, they will be given over to the THPs to plant at home. Local resistance to using the artificially propagated plants was cited as a potential challenge, but so far this has not been the case. Further challenges arise when defining which user groups should be targeted in awareness initiatives. Only a small percentage of the THPs who work in the communities neighbouring the KNP can be directly involved in the workshops owing to resource limitations, and so selecting the participants in a transparent and fair way is challenging. Furthermore, since it may be that illegal harvesting by outsiders supplies commercial markets in the large cities, targeting only local THPs may not be effective in protecting wild populations of $W$. salutaris in the KNP. Identifying the demand and supply chain to commercial markets will play an important role in the identification of target groups for outreach initiatives. During the 2009 field trip, it was speculated that the harvesting methods originally used were different from those used to cause more recent damage, as older tree scars were made by strip- rather than ring barking. The former resulted in better bark recovery than the latter, as the main part of the stem remained untouched (Swemmer 2010).

\section{Lessons learnt from the case study}

Key lessons have been learnt from the adaptive management approach.

- A thorough understanding of the reproductive biology and regeneration mechanisms of $W$. salutaris is needed to refine the monitoring programme and the associated set of TPCs further.

- Understanding the drivers of the demand for the resource is essential if SANParks wants to reduce pressure on wild populations. Employing field rangers to protect the trees may be effective in the short term, but without addressing the larger drivers of demand pressure on the plants will not be reduced.

- Linking management interventions to the appropriate drivers at appropriate scales should be a priority during the adaptive planning and management phases.

- Continuous engagement with user groups is essential to monitor and adapt to long-term social and economic impacts of harvesting programmes.

- In the case of W. salutaris, a multi-pronged, multi-scaled approach seems to be most effective.

- Although W. salutaris is an endangered plant, an approach that involves a small-scale harvesting programme (controlled access) may be more effective than a nonharvesting approach (no access).

- A clear conceptual framework of how the system works, what the drivers are and what response variables can be measured and monitored is essential to guide the development of clear programme objectives. The objectives should be linked to clear measurables and deliverables and associated time frames.

- Identifying and getting agreement on roles and responsibilities in multidisciplinary projects can be challenging, and requires an overarching strategic plan that is developed, implemented and monitored together with all relevant stakeholders.

\section{Case study 3: Sour fig (Carpobrotus acinaciformis) harvesting in Agulhas National Park Introduction}

The Agulhas region has a history of sour fig harvesting (Cowling \& Richardson 1995; ed. Hassan 2002; Hudson 2009). Two species, Hottentot fig (Carpobrotus edulis [L.] N.E. Br.) and sour fig (Carpobrotus acinaciformis [L.] L. Bol.), occur here. However, local resource users prefer the suurvy for its sweeter fruits and greater yield (Scheepers 2008a). The high demand for a single species highlights the potential for overuse yet the quantities harvested and the associated impacts on biodiversity have never been monitored. With the establishment of the Agulhas National Park (ANP), the challenge of sustainable resource use was inherited by park management.

Legitimate resource users are recognised as those stakeholder groups that have traditionally harvested sour figs in the Agulhas region. They include the poor and unemployed, schoolgoing children, pensioners, the public, tourists and local farm labourers. However, most resource users are residents of the local settlements of Struisbaai and Buffelsjag, where sour fig harvesting underpins subsistence and smallscale commercial use.

Faced with shortfalls in local law enforcement capacity, it has proven difficult to provide legitimate users with secure resource use rights and to exclude outsiders and opportunists (Oström 1990; Sandström 2009). Large-scale commercial 
traders operating at the regional level often rely on local labour pools to create a monopoly on trade that undercuts small-scale local business (Scheepers 2008a). Consequently, the challenge of providing for a fair and equitable distribution of benefits from sour fig harvesting requires a multifaceted approach.

Faced with high current demands for the resource and a historical precedent of use, SANParks must make management decisions based on the best available science (Biggs \& Rogers 2003). Adaptive management is therefore necessary. Because people's livelihoods are affected by changes in the resource use management of the park, a sense of urgency drives the need for management experiments to trial different monitoring methods, governance arrangements and ways to integrate local and scientific knowledge to foster learning.

\section{Socio-economic aspects}

Fresh sour figs are used to make jams and preserves or are eaten as dried fruits. Fresh figs are sold at R15/ kg while dried figs are worth $\mathrm{R} 10 / \mathrm{kg}$ on the local market. During a study of sour fig harvesting as a potential community development initiative, Farabi and Associates (2008) estimated that $3 \mathrm{~kg}$ of sour figs are currently harvested per hectare on between 3000 ha and 5000 ha of the park, producing an annual yield of $9000 \mathrm{~kg}-15000 \mathrm{~kg}$. The annual contribution to the local economy (fresh and dried figs, combined) was estimated at R90 000-R225 000 (Farabi \& Associates 2008).

At the household level, an average annual income of R738 per person from sour fig harvesting was calculated for the period between 2005 and 2009. Although only a seasonal resource, one benefit of sour fig harvesting is that people can bolster their cash reserves for the start of another year. The additional income is particularly important as most sour fig harvesters are pensioners (57\%). Only $29 \%$ of local resource users were income earners.

\section{Ecological studies}

Little monitoring of sour fig harvesting in the park has taken place. However, certain areas are preferentially selected by local resource users while others are avoided, which introduces the risk that some areas will be overexploited. Although not of concern in itself while ecosystem integrity appears to be maintained, a lack of feedbacks in the socioecological system to prompt management interventions poses a greater, more long-term problem.

During the 2009 harvesting season, the first monitoring plots for sour fig harvesting were established to generate baseline data. The survey results showed no significant differences in sour fig numbers across the park. This finding indicated that people's resource use patterns were likely not driven by resource availability. However, further monitoring across a more representative sample of plots is required to test this hypothesis.

The survey also did not find signs of sour fig harvesting for which there were many possible explanations. Monitoring was undertaken at the beginning of the season while harvesting began later owing to a late fruiting season caused by unusual weather conditions. Sour figs may also occur within a patchier distribution than expected, as indicated by gaps in people's local knowledge of the best harvesting areas.

Household surveys amongst local resource users showed that only $2169 \mathrm{~kg}$ sour figs were harvested, supporting the theory that the harvesting season produced a low yield. However, this figure did not take into account illegal sour fig harvesting. The reliability of the survey data was also dependent on the local resource users reporting the actual quantities harvested.

Continued monitoring is required to gain a better understanding of current resource use patterns. However, interviews indicated that people's resource use patterns are driven by a cultural preference for $C$. acinaciformis over $C$. edulis and resource accessibility, which is likely a complex function of multiple entry points to the park, the limited road network, the method of travel (i.e. whether walking or driving), and the distance covered by resource users in search of sour figs. Most users (57\%) stated that they harvested the preferred species but travelled greater distances now than in the past to harvest the same quantities.

\section{Application of adaptive management to monitor sour figs}

In response to the overexploitation of sour figs in some areas, SANParks initially established a uniform harvest prescription of no more than $30 \%$ of the available yield across the park (Farabi \& Associates 2008). This was never successfully implemented. Without adequate stakeholder involvement and support, the harvest prescription was largely imposed by SANParks on the local resource users. Local people questioned the legitimacy of the decision and perceived the restriction on harvesting as unfair, particularly as poor law enforcement failed to curb illegal use. Local users also found the percentage of available yield harvested as an indicator for sustainable use difficult to understand.

Adaptive management emerged as an alternative. It entailed a process of collaborative problem framing, planning, implementation and evaluation together with local resource users and other relevant stakeholders (Cundill \& Fabricius 2009). This participatory approach to management enhanced stakeholder engagement through the creation of platforms for dialogue concerning the need to monitor sour fig harvesting, and the creation of incentives for sustainable use. It also fostered better relations between the community and law enforcement authorities such that the increase in social capital helped buffer local resource users and law enforcement against future conflicts; in fact, registered resource users have started to report incidents of illegal use to the authorities.

An adaptive management approach also allowed for the recognition of different intensities of use by local resource users across the park. Consequently, separate harvesting areas were assigned to each of the two major resource user 
groups at Struisbaai and Buffelsjag. Designated areas of high, moderate and no use also continue to allow for a diversity of impacts from sour fig harvesting across the park. This mosaic of harvesting intensities, in turn, informs an experimental design for the development of sustainable resource use TPCs across the park in future.

However, indicators more appropriate to the local context are needed in order for resource users to understand and support the implementation of a monitoring system. As local users harvest sour figs in standard-sized shopping bags, the number of bags harvested and their mass represent potential alternatives to the percentage yield harvested. With continued monitoring, the quantities of sour figs harvested from the park can be compared with household surveys to identify discrepancies between observed and expected levels of use, monitor trends and inform research priorities. The calculation of preference indices (Scheepers 2008b; Shackleton 1993) for the different harvesting areas across the park can help highlight areas of overexploitation. The income generated from sales can be used to track financial benefits from sour fig harvesting for local people. The use of multiple indicators also makes it more difficult for opportunists and outsiders to break the rules (Fabricius et al. 2007; Oström 1990).

\section{Integration of local and scientific knowledge}

In response to an unsuccessful first attempt to manage sour fig harvesting, SANParks adopted a more participatory approach, which aimed to link stakeholder aspirations to management actions (Cundill \& Fabricius 2009). Current stakeholder participation is consultative, as local resource users make inputs into the management process at every stage (Fabricius 2004). Participatory research techniques such as transect walks, questionnaire surveys, user group discussions and workshops capture inputs from local resource users to inform management decisions about appropriate monitoring indicators and local governance arrangements.

Creating more opportunities for dialogue has also improved communication between the park and local resource users. Whereas communication mostly occurred during the buildup to the harvesting season in the past, year-round activities that include planning, monitoring, data analysis, reporting and reflection promote co-learning through the management process. As part of the new resource use protocols, for example, local resource users are required to make inputs into an annual report, working with SANParks scientists and the staff from the People and Conservation division.

In turn, high levels of support by SANParks and others have encouraged local resource users to become complaisant. While SANParks has played a greater advisory role to resource users in the past, poor local leadership and inadequate capacity building may explain the current lack of community ownership of the project. Transition strategies are needed if greater responsibility is to be given to local resource users to monitor their own use in the long term. These strategies could include mentorship opportunities, leadership training, sharing experiences, reciprocal knowledge transfers and management workshops.

\section{Flexible institutions}

Local resource users were initially organised into respective community associations for Buffelsjag and Struisbaai. Each group developed their own constitution and code of conduct, which SANParks recognised (Fabricius et al. 2004). However, these rules were never revisited as member numbers increased and social cohesion within the groups became stressed. As conflicts arose, the community associations were ill equipped to resolve them. Successive mergers and splits from the original groups occurred and as communication networks broke down, confusion resulted over membership lists and examples of nepotism were observed within the management structure. Consequently, an investment in conflict resolution mechanisms, including the use of an independent arbitrator on a case-by-case basis, is necessary to strengthen local governance. Over the long term, processes of deliberation, negotiation, and the development of social capital and trust amongst resource users must be in place as part of everyday management (Sandström 2009).

Flexible rules for governing sour fig harvesting were developed to be sensitive to local conditions (Fabricius 2004; Oström 1990). These include harvesting times that are outside the hottest time of the day. The time restrictions also help local law enforcers to distinguish between legitimate and unlawful resource users, as illegal harvesting mostly takes place at night. However, as all offences are equally punishable, many registered users (43\%) said that there is little incentive for sustainable resource use. Instead, people stated that they were disadvantaged by 'doing the right thing', as this required the payment of an administration fee for a harvesting permit while illegal resource users were seldom caught. To influence people's attitudes and actions in favour of sustainable use, graduated sanctions for offences and improved law enforcement efforts are required at the ANP.

\section{Lessons learnt from case study}

Several lessons emerged from the implementation and ongoing management as described in this case study.

- An adaptive management approach is necessary where faced with a historical precedent of use, high demands for the resource and little baseline data. As sour figs were harvested from the area prior to the establishment of the park, it was difficult for SANParks to implement restrictions on use pending the necessary research and monitoring to set sustainable use levels without adequate involvement from the local resource users.

- As shown by Shackleton and Shackleton (2004), moderate socio-economic benefits from sustainable resource use can make a significant contribution to people's livelihoods when available at strategic times of the year. The seasonal income from sour fig harvesting supplements household budgets over the December holiday season and helps kick-start the new year.

- Long-term monitoring data and appropriate ecological and socio-economic indicators of change are needed to inform TPCs for the sustainable use of sour figs at the ANP. The number of bags harvested by local resource 
users, identification of preferred harvesting areas, and the income generated from sales may be good indicators of sustainable use but should be tested and refined through ongoing research and monitoring.

- A participatory approach supports the legitimacy of management decisions regarding sustainable resource use (Cundill \& Fabricius 2009). Communication between the park, local resource users and other stakeholders was improved through the creation of additional platforms for dialogue, enhanced stakeholder relationships, and the incorporation of local knowledge into management.

- A mosaic of harvesting intensities across the park promotes habitat heterogeneity, while the designation of a no-use area allows for ecosystem renewal (Biggs \& Rogers 2003). The experimental design of high, moderate and no-use areas also allows for the development of multiple TPCs for sustainable use.

- Responsible facilitation and the co-management of resources require transitional strategies that will empower local resource users to become self-governing (Fabricius et al. 2004). In the case of sour fig harvesters in the ANP, these transitional strategies should focus on leadership development, training in monitoring resource use and conflict resolution.

- There need to be adequate incentives for local resource users to support sustainable use practices. Improved law enforcement and graduated sanctions for offences that distinguish between the actions of registered and unlawful resource users can create this incentive for sustainable sour fig harvesting in the ANP.

\section{Conclusions}

The SANParks policy on resource use (SANParks 2008) embraces a systems view of sustainable resource use with ecological and socio-economic drivers that link the management of national parks to their surrounds. The case studies in this paper inform the implementation of the policy and promote learning through an adaptive management framework.

One lesson is that the identification of appropriate indicators and the setting of acceptable limits of change should be part of a dynamic process informed by ongoing monitoring and research. However, faced with incomplete knowledge of the ecological and socio-economic factors driving resource use, the precautionary principle must always be applied (Cooney 2004). In the first two case studies, the impacts of harvesting were initially underestimated, whereas they were overestimated in the third, with potentially large implications for socio-economic benefits from resource use.

The zonation of different areas for use, as in the first and third case studies, sets up an experimental design to develop TPCs that support flexible rules for management. Multiple overlapping sets of rules facilitate effective monitoring, and make it more difficult for oppportunists and outsiders to break the rules (Fabricius et al. 2007; Oström 1990). This applies particularly where incentives for sustainable use and resource protection are linked to strict law enforcement, as in the case of haversting pepper-bark tree and sour figs.
A participatory research approach in all case studies enabled the incorporation of local knowledge into the management process. However, as shown for the sour fig case study, responsible facilitation and the co-management of resources require transitional strategies that empower local resource users to become self-governing (Fabricius et al. 2004). Without adequate capacity building, new dependencies can be created and local resource users may become complaisant.

Other challenges raised by the case studies include the development of too few ecological TPCs, with the exception of those for pepper-bark tree harvesting. A common explanation is the lack of long-term monitoring data and a poor understanding of the ecological drivers of resource use. Further research into the population dynamics, demography and reproductive phenology of plant resources are required to refine indicators for monitoring and determine TPCs for their sustainable use. However, with the exception of the KNP, using TPCs as part of the management of South African national parks is new. Therefore, it will be some time before the usefulness of the concept can be evaluated at the national scale.

No socio-economic TPCs for sustainable resource use have been developed. Possible explanations include a historical bias towards ecological over social science research and limited in-house capacity to develop the necessary monitoring and evaluation systems. Methods to quantify and monitor intangible benefits from sustainable resource use should also be developed. The case studies suggest multiple drivers of sustainable resource use across various scales. Consequently, SANParks will need to invest in the necessary resources and capacity building to ensure effective management systems. Partnerships with the private sector and local resource users, as in the case of seven-weeks fern harvesting, represent a possible mechanism for leveraging opportunities for sustainable resource use.

\section{References}

Abbot, J.I.O. \& Mace, R., 1999, 'Managing protected woodlands: Fuelwood collection and law enforcement in Lake Malawi National Park', Conservation Biology 13(2), 418-421. doi:10.1046/j.1523-1739.1999.013002418.x

Biggs, H.C. \& Rogers, K.H., 2003, 'An adaptive system to link science, monitoring, and management in practice', in J.T. du Toit, K.H. Rogers \& H.C. Biggs (eds.), The Kruger experience: Ecology and management of savanna heterogeneity, pp. 59-80, Island Press, Washington DC.

Botha, J., Witkowski, E.T.F. \& Shackleton, C.M., 2004, 'The impact of commercial harvesting on Warburgia salutaris ('pepper-bark tree') in Mpumalanga, South Africa', Biodiversity and Conservation 13, 1675-1690. doi:10.1023/ B:BIOC.0000029333.72945.b0

Bulte, E.H., Van Kooten, G.C. \& Swanson, T., 2003, 'Economic incentives and wildlife conservation', viewed 21 July 2010, from http://www.cites.org/eng/prog/ economics/CITES-draft6-final.pdf

Clover, J. \& Eriksen, S., 2009, 'The effects of land tenure change on sustainability: Human security and environmental change in southern African savannas', Environmental Science and Policy 12, 53-70. doi:10.1016/j.envsci.2008.10.012

Cooney, R., 2004, 'The precautionary principle in biodiversity conservation and natural resource management: an issues paper for policy-makers, researchers and practitioners', IUCN, Cambridge.

Cowling, R. \& Richardson, D., 1995, Fynbos: South Africa's unique floral kingdom, Fernwood Press, Vlaeberg.

Cundill, G. \& Fabricius, C., 2009, 'Monitoring in adaptive co-management: Toward a learning based approach', Journal of Environmental Management 90, 3205-3211. doi:10.1016/j.jenvman.2009.05.012, PMid:19520488

Cunningham, A.B., 2001, Applied ethnobotany: People, wild plant use and conservation, Earthscan Publications, London.

Diederichs, N., 2006, Commercializing medicinal plants: a Southern African guide, Sun Press, Stellenbosch. 
Fabricius, C., 2004, 'The fundamentals of community-based natural resource management', in C. Fabricius, E. Koch, H. Magome \& S. Turner (eds.), Rights,

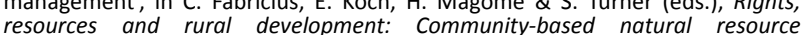
management in Southern Africa, pp. 3-43, Earthscan, London.

Fabricius, C., Folke, C., Cundill, G. \& Schultz, L., 2007, 'Powerless spectators, coping actors, and adaptive co-managers: A synthesis of the role of communities in ecosystem management', Ecology and Society 12(1), 29, viewed 17 August 2010, from http://www.ecologyandsociety.org/vol12/iss1/art 29

Fabricius, C., Koch, E., Magome, H. \& Turner, S., 2004, Rights, resources and rural development: Community-based natural resource management in Southern Africa, Earthscan, London.

Farabi and Associates, 2008, 'Agulhas National Park: Suurvye harvesting', consultants' report, Farabi and Associates, Pretoria.

Geldenhuys, C.J., 1993, 'Composition and dynamics of plant communities in the southern Cape forests', Deliverable Report No. FOR-DEA 612, Division of Forest Southern Cape forests', Deliverable Report No. FOR-DEA 612, Division of Forest
Science and Techology, Council for Scientific and Industrial Research, Pretoria.

Geldenhuys, C.J., 1994, 'Review of studies of the fern Rumohra adiantiformis in the southern Cape forests: Implications for sustainable management', Deliverable Report No. FOR-DEA 758, Division of Forest Science and Technology, Council for Scientific and Industrial Research, Pretoria.

Geldenhuys, C.J., 2000, 'Sustained yield determination of forest and woodland produce', in D.L. Owen \& W.J. Vermeulen (eds.), South African forestry handbook 2000, pp. 643-650, Southern African Institute of Forestry, Pretoria.

Geldenhuys, C.J. \& Van der Merwe, C.J., 1986, 'Effects of frond harvesting on growth of the fern Rumohra adiantiformis in the southern Cape forests', Research Report S. 30/85, Saasveld Forestry Research Centre, George.

Geldenhuys, C.J. \& Van der Merwe, C.J., 1988, 'Population structure and growth of the fern Rumohra adiantiformis in relation to frond harvesting in the southern Cape fern Rumohra adiantiformis in relation to frond harvesting
forests', South African Journal of Botany 54(4), 351-362.

Geldenhuys, C.J. \& Van der Merwe, C.J., 1994, 'Site relations and performance of Rumohra adiantiformis in the southern Cape forests', Deliverable Report FOR-DEA 759, Division of Forest Science and Technology, Council for Scientific and Industrial Research, Pretoria.

Hansen, A.J. \& DeFries, R., 2007, 'Ecological mechanisms linking protected areas to surrounding lands', Ecological Applications 17, 974-988. doi:10.1890/05-1098, PMid:17555212

Hassan, R.M. (ed.), 2002, Accounting for stock and flow values of woody land resources: Methods and results from South Africa, CEEPA, University of Pretoria, Pretoria.

Hilton-Taylor, C., Scott-Shaw, R., Burrows, J. \& Hahn, N., 1998, 'Warburgia salutaris' in IUCN Red List of Threatened Species, viewed 13 April 2010, from http://www. iucnredlist.org

Hoole, A. \& Berkes, F., 2010, 'Breaking down fences: Recoupling social-ecological systems for biodiversity conservation in Namibia', Geoforum 41, 304-317. systems for biodiversity conservation
doi:10.1016/j.geoforum.2009.10.009

Hudson, V., 2009, 'The harvesting of sour figs (Carpobrotus edulis) on CapeNature Reserves on the Agulhas Plain', paper presented at Botanical Society of South Africa Conference, Bredasdorp, 4-7th August.

International Union for Conservation of Nature, 2010, IUCN Red List of Threatened Species, viewed 01 April 2010, from http://www.iucnredlist.org

IUCN. See International Union for Conservation of Nature.

Kok, H.R., 1998, 'Studie na die volhoubare benutting van seweweeksvaring (Rumohra adiantiformis) uit die inheemse woude van die Suid-Kaap en Tsitsikamma', MSc dissertation, Department of Environmental Management and Ecology, University of the Orange Free State.

Lindsey, P.A., Roulet, P.A. \& Romañach, S.S., 2007, 'Economic and conservation significance of the trophy hunting industry in sub-Saharan Africa', Biological Conservation 134, 455-469. doi:10.1016/j.biocon.2006.09.005

Lumbe, A., 2008, e-mail, 13 November 2008, andrewl@sanparks.org

Mander, M., 1998, Marketing of indigenous medicinal plants in South Africa. a case study in KwaZulu-Natal, Food and Agricultural Organisation, United Nations, Rome.

Milton, S.J., 1987a, 'Growth of seven-weeks fern (Rumohra adiantiformis) in the southern Cape forests: Implications for management', South African Forestry southern Cape fornal 143, 1-4.
Jour

Milton, S.J., 1987b, 'Effects of harvesting on four species of forest ferns in South Africa', Biological Conservation 41, 133-146. doi:10.1016/0006-3207(87)90116-9

Milton, S.J., 1991, 'Slow recovery of defoliated seven-weeks fern Rumohra adiantiformis in Harkerville Forest', South African Forestry Journal 158, 23-27.

Milton, S.J. \& Moll, E.J., 1987, 'Utilisation potential of Rumohra adiantiformis in the southern Cape forests', Forest Biome Project Report, Ecosystem Programmes, Foundation for Research Development/Council for Scientific and Industrial Research, Pretoria.

Milton, S.J. \& Moll, E.J., 1988, 'Effects of harvesting on frond production of Rumohra adiantiformis (Pteridophyta: Aspidiaceae) in South Africa', Journal of Applied Ecology 24, 725-743. doi:10.2307/2403858

Murphree, M.W., 2000, 'Community-based conservation: Old ways, new myths and enduring challenges', key address at the conference on African wildlife management in the new millennium, College of African Wildlife Management, Mweka, 13-15th December.
Nagothu, U.S., 2001, 'Fuelwood and fodder extraction and deforestation: Mainstream views in India discussed on the basis of data from the semi-arid region of Rajasthan', Geoforum 32, 319-332. doi:10.1016/S0016-7185(00)00034-8

Natural Justice, 2010, 'Biocultural protocol of the traditional health practitioners of Bushbuckridge', Natural Justice, Mpumalanga Tourism and Parks Agency and the Traditional Health Practitioners of Bushbuckridge, viewed 19 April 2011, from http://www.naturaljustice.org/images/naturaljustice/bushbuckridge\%20k2c\%20 bcp.pdf

Oström, E., 1990, Governing the commons: The evolution of institutions for collective action, Cambridge University Press, Cambridge.

Parr, C.L., Woinarski, J.C.Z. \& Pienaar, D.J., 2009, 'Cornerstones of biodiversity conservation? Comparing the management effectiveness of Kruger and Kakadu National Parks, two key savanna reserves', Biodiversity Conservation 18, 3643-3662. doi:10.1007/s10531-009-9669-4

Peters, C.M., 1996, 'The ecology and management of non-timber forest resources', Technical Paper No. 322, World Bank, Washington DC.

Reid, H. \& Turner, S., 2004, 'The Richtersveld and Makuleke contractual parks in South Africa: Win-win for communities and conservation?', in C. Fabricius, E. Koch, H. Magome \& S. Turner (eds.), Rights, resources and rural development: communityMagome \& $\mathrm{S}$. Turner (eds.), Rights, resources and rural development: community-
based resource management in Southern Africa, pp. 223-234, Earthscan, London.

Reid, H., Fig, D., Magome, H. \& Leader-Williams, N., 2004, 'Co-management of contractual national parks in South Africa: Lessons from Australia', Conservation and Society 2(2), 377-409.

SANBI. See South African National Biodivesity Institute.

SANParks. See South African National Parks.

Sandström, C., 2009, 'Institutional dimensions of comanagement: Participation, power, and process', Society and Natural Resources 22(3), 230-244. doi:10.1080/08941920802183354

Scheepers, K., 2008a, 'Research trip to Agulhas NP: Towards formalizing suurvye harvesting in the park', internal report, Cape Research Centre, South African harvesting in the
National Parks.

Scheepers, K., 2008b, 'Harvesting strategies of fuelwood and kraalwood users at Machibi: identifying the driving factors and feedbacks', PhD thesis, Department of Environmental Science, Rhodes University.

Scherl, L.M., Wilson, A., Wild, R., Blockhus, J., Franks, P., McNeely, J.A., et al., 2004, 'Can protected areas contribute to poverty reduction? Opportunities and limitations', IUCN, Cambridge, UK. doi:10.2305/IUCN.CH.2005.6.en

Shackleton, C.M., 1993, 'Fuelwood harvesting and sustainable utilisation in a communal grazing land and protected area of the eastern Transvaal lowveld', Biological Conservation 63, 247-254. doi:10.1016/0006-3207(93)90720-L

Shackleton, S. \& Shackleton, C., 2004, 'Everyday resources are valuable enough for community-based natural resource management programme support: Evidence from South Africa', in C. Fabricius, E. Koch, H. Magome \& S. Turner (eds.), Rights, resources and rural development: Community-based natural resource management in Southern Africa, pp. 135-146, Earthscan, London.

South African National Biodivesity Institute, 2009, National Red List of South African plants, South African National Biodivesity Institute, Pretoria.

South African National Parks, 2008, SANParks Resource Use Policy, South African National Parks, Pretoria.

Stankey, G.H., Clark, R.N. \& Bormann, B.T., 2005, 'Adaptive management of natural resources: Theory, concepts, and management institutions', General Technical Report PNW-GTR-654, United States Department of Agriculture, Forest Service, Pacific Northwest Research Station.

Swemmer, L.K., 2006, 'Report on Rare and Invasive Species Programme', internal report, Kruger National Park, South African National Parks.

Swemmer, L.K., 2010, 'Warburgia salutaris Conservation Programme', internal report, Scientific Services, South African National Parks.

Vermeulen, W.J., 2009, 'The sustainable harvesting of non-timber forest products from natural forests in the southern Cape, South Africa: Development of harvest systems and management prescriptions', PhD thesis, Department of Conservation systems and management prescriptions', PhD thesis,

Vermeulen, W.J., Du Plessis, L. \& Herd, H., 2005, 'Harvesting of Seven Weeks fern (Rumohra adiantiformis) from natural forests of the southern Cape', in Participatory forest management. Case studies in South Africa 2005, pp. 83-88, Department of Water Affairs and Forestry, Pretoria.

Von Breitenbach, F., 1968, Southern Cape indigenous forest management manual, Foundations of Management, Department of Forestry, George.

Von Maltitz, G.P. \& Shackleton, S.E., 2004, 'Use and management of forests and woodlands in South Africa: Stakeholders, institutions and processes from past to present', in M.J. Lawes, H.A.C. Eeley, C.M. Shackleton \& B.G.S. Geach (eds.), Indigenous forests and woodlands in South Africa: Policy, people and practice, pp. 109-135, University of KwaZulu-Natal Press, Durban.

Willis, C.B., 2004, 'Policy frameworks pertaining to the conservation and sustainable use of forests and woodlands in South Africa', in M.J. Lawes, H.A.C. Eeley, C.M. Shackleton \& B.G.S. Geach (eds.), Indigenous forests and woodlands in South Africa: Policy, people and practice, pp. 77-107, University of KwaZulu-Natal Press, Durban.

Zambatis, N., 2006, 'Report on the state of the Pepper-bark Tree (Warburgia salutaris) in the KNP', internal report, Kruger National Park, South African National Parks. 